\title{
CRITICAL REVIEW OF MODERN NUMERICAL MODELLING OF SNOW ACCUMULATION ON ROOFS WITH ARBITRARY GEOMETRY
}

\author{
A.M. Belostotsky ${ }^{1,2,3}$, N.A. Britikov ${ }^{2,3}$, O.S. Goryachevsky ${ }^{1,2}$ \\ ${ }^{1}$ Scientific Research Center StaDyO, M oscow, RUSSIA \\ ${ }^{2} \mathrm{~N}$ ational Research M oscow State University of Civil Engineering, M oscow, RUSSIA \\ ${ }^{3}$ Russian University of Transport (RUT - M IIT), M oscow, RUSSIA
}

\begin{abstract}
The calculation of snow loads on roofs of buildings and structures with arbitrary geometry is a complex problem, solving which requires simulating snow accumulation with acceptable engineering accuracy. Experiments in wind tunnels, although widely used in recent years, do not allow to reproduce the real full-scale effects of all snow transport subprocesses, since it is impossible to satisfy all the similarity conditions. This situation, coupled with the continuous improvement of mathematical models, numerical methods, computer technologies and related software, makes the development and future implementation of numerical modelling in real construction practice and regulatory documents inevitable. This paper reviews currently existing mathematical models and numerical methods used to calculate the forms of snow deposits. And, although the lack of significant progress in the field of modelling snow accumulation still remains one of the major problems in CFD, use of existing models, supported by field observations and experimental data, allows to reproduce reasonably accurate snow distributions. The importance of the "symbiosis" between classical experimental methods and modern numerical models is specifically emphasized in the paper, as well as the fact that only the joint use of approaches can comprehensively describe modelling of snow accumulation and snow transport and provide better solutions to a wider range of problems.
\end{abstract}

Keywords neural networks, numerical modelling, snow accumulation, snow transport, structure roofs, numerical methods.

\section{СОВРЕМЕННЫЕ МЕТОДЫ МАТЕМАТИЧЕСКОГО (ЧИСЛЕННОГО) МОДЕЛИРОВАНИЯ СНЕГОНАКОПЛЕНИЯ НА ПОКРЫТИЯ СООРУЖЕНИЙ ПРОИЗВОЛЬНОЙ ФОРМЫ. КРИТИЧЕСКИЙ ОБЗОР}

\author{
Белостоцкий А.М. ${ }^{1,2,3}$, Бритиков Н.А. ${ }^{2,3}$, Горячевский О.С. ${ }^{1,2}$ \\ ${ }^{1}$ Научно-исследовательский центр СтаДиО, г. Москва, РОССИЯ \\ ${ }^{2}$ Национальный исследовательский Московский государственный строительный университет, \\ г. Москва, РОССИЯ \\ ${ }^{3}$ Российский университет транспорта (МИИТ), г. Москва, РОССИЯ
}

\begin{abstract}
Аннотация: Расчёт снеговых нагрузок на покрытия зданий и сооружений произвольной формы является комплексной задачей, для решения которой необходимо С приемлемой инженерной точностью моделировать снегонакопление. Эксперименты в аэродинамических трубах, хотя и применяются последние годы повсеместно, не позволяют воспроизвести реальные полномасштабные эффекты всех процессов снегопереноса, поскольку выполнение всех условий подобия для них невозможно. Такая ситуация, вкупе с постоянным развитием математических моделей, численных методов и соответствующего программного обеспечения, вычислительной техники делает безальтернативным развитие и будущее внедрение технологий математического моделирования в реальную строительную практику и нормативные документы. В данной работе рассмотрены существующие на сегодняшний день математические модели и численные методы, применяемые для расчёта форм снегоотложений. И хотя отсутствие значительного прогресса в области моделирования снегонакопления по-прежнему остаётся одной из проблем вычислительной аэродинамики, использование уже существующих моделей, подкреплённое натурными наблюдениями и экспериментальными данными, способно воспроизводить достаточно
\end{abstract}


точные картины распределений снега. В работе отдельно подчёркнута важность «симбиоза» между классическими экспериментальными методами и современными численными моделями и того, что только совместное использование подходов способно всесторонне раскрыть проблему моделирования снегоотложений и снегопереноса и дать наилучшее её решение для широкого спектра задач.

Ключевые слова: нейронные сети, математическое моделирование, снегонакопление, снегоперенос, покрытия сооружений, численные методы.

\section{INTRODUCTION}

Snow accumulation (the formation of snow deposits under the influence of air flow) is a complex phenomenon due to the high nonlinearity of its constituent subprocesses, which occur at different scales and are strongly interconnected $[2,3,21]$. One of those, snow transport, is the subject of many years of theoretical, experimental and numerical research $[19,27]$ because of its involvement in the redistribution of snow masses. The fact that the formation of fairly uniform snowdrifts occurs as a result of the gradual deposition of snowflakes with sizes from tens of microns to tens of millimeters [9] makes a serious computational problem, especially considering that in most industries, where it matters, it must be considered on areas of tens and hundreds of square meters [22].

The known disadvantages of experimental methods for predicting the shape of snow deposits (the use of substitutes, such as sand [23], sawdust [11] and others, loss of accuracy due to scaling, etc.) and the natural randomness of weather conditions that affect field observations force researchers to use numerical methods, which makes it possible to effectively model the properties of real materials at required scales and control all the calculation parameters.

One of the fields that certainly require a computational approach is the construction of unique buildings and structures. Due to the dependence of the snow accumulation process on the geometry of the structure, surrounding buildings, landscape, and climatic conditions, it is necessary to investigate snow loads for each unique roof design. Regulatory documents describe the shape of snow deposits only for basic, typical roofs. Also note that foreign building codes
(ISO 4355-2016 [46], Eurocode [5], ASCE standards [24], JSCE [25]), in contrast to the Russian Building Code [26], allow the use of numerical modelling of snowdrifts both together with the results of experimental modelling and to verify the results of experiments, as well as instead of experiments where it is impossible to conduct studies in wind tunnels. E.g., in a separate ASCE standard [42] there is a subsection dedicated specifically to the study of methods for modelling snow transport, their classification and discussion of the limits of their applicability [52].

In connection with the growing tendency to reduce the costs of construction, which puts significant restrictions on the design, the use of numerical modelling could also upgrade the building codes. For example, some researchers believe [19] that the use of the Weibull and Gumbel distributions, which is currently the accepted way to estimate the amount of precipitation, leads to overestimation of the snow loads. Predicting the movement of snow masses in the mountains, formation of avalanches, as well as other natural phenomena associated with snow that threaten human lives, also remains an important and generally unsolved problem [13, 14].

Over the past decades, a standardized, verified and effective numerical methodology for modelling snow accumulation and snow transport, which could be integrated in the building codes, has not been created, despite the increased demand from industries [19]. Obviously, this is due to the imperfection of existing models and methods and lack of qual itative achievements in their development. Since about 2014, there has been an increase in the number of works on the numerical modelling of snow accumulation and 
snow transport from China [23, 36, 37, 44, 45], supported by government grants and aimed at upgrading building codes, which will probably lead to verified methodologies emerging soon.

Few Russian scientific works on the topic [47, $48,49,50,51]$, on the contrary, are mostly derivative in nature, despite the problem of calculating snow loads on the roofs of buildings and structures with arbitrary geometry in our country being way more relevant due to the features of the climate. E.g., one of the more well-known articles [47] contains only a brief overview of some (far from all) works on modelling snow accumulation, does not provide any new results, does not raise important issues of the development and improvement of techniques, as well as their introduction into construction practice, while another example [51] is actually a literal translation of the A SCE standard [42]. The lack of critical reviews that clearly highlight the gap between the regulations and industry demands further aggravates the situation and delays the necessary resolution of the issue.

The problem of numerical modelling of snow accumulation has existed for at least 40 years [19]. Over the time, a number of studies have been carried out and numerical methods and approaches have been developed that, to one degree or another, bring scientists closer to achieving more and more physically realistic forms of snow deposits. $V$ alidation of numerical methods was carried out mainly on model cases for which there were data from field observations or experiments in wind tunnels, e.g. for the flow around a cube $[12,20,32,33]$ or a solid fence $[11,20]$. Some scientists have tried to apply the models to real-life problems, such as the accumulation of snow on the roofs of buildings [22, $34,35,36,37,44]$ or around buildings or landscape formations [16, 17, 38, 39, 40,41,45]. In each case, it was necessary to calibrate the models for the specific conditions of the given problem and to individually select the parameters, although even then minimizing the divergences with observations was not sufficient to speak of an "accurate" reproduction of "real" snow deposits [19]. One of the reasons for this is that to adequately model snow transport for arbitrary wind velocities, structural geometries and climatic parameters, it is necessary to take into account all three subprocesses, but in practice it is difficult to do because of scales at which they occur. Of greatest interest is the modelling of suspension and saltation, since it is they that make the greatest contribution to the actual transport of snow (especially saltation, due to the large scatter of particle sizes and lengths up to $5 \mathrm{~m}$ of which they are capable to move).

\section{THE PHENOMENON OF SNOW TRANSPORT}

One of the fundamental works on the mechanics of aeolian transport (that is, movement of solid particles, or sediments, under the influence of wind), which formed the basis of the vast majority of theoretical developments on this issue, are the works of R.A. Bagnold [2, 3]. He laid the foundation for a scientific approach to describing the transport of sand by wind, the formation of sand dunes and barchans. The experiments, results of which are presented in the book, were carried out in a wind tunnel built by the scientist himself. When considering the problem of modelling snow deposits, the information from this book is also relevant, since snow, like sand, participates in aeolian transport. However, sand grains do not have the property of cohesion, unlike snowflakes, due to which the snow transport can be divided into three subprocesses, namely creep, saltation and suspension (Fig. 1) $[3,19]$.

1) Creep is a phenomenon in which coarse sediments ( $500 \mu \mathrm{m}$ in diameter) are rolling over the surface due to their cohesion with it being stronger than the wind force.

2) Saltation is a jumping movement of mediumsized particles (70-500 $\mu \mathrm{m})$ at a speed 2-3 times lower than the flow speed. Particles up to 100 $\mu \mathrm{m}$ in diameter are subject to modified saltation, which occurs under the action of turbulent vortices above the surface. The mass of material 
that the flow is able to transport in the saltation layer is determined by the formula (1).

3) The suspended layer is formed from fine sediments and is divided into short-term suspension (20-70 $\mu \mathrm{m}$, particles return to the saltation layer) and long-term suspension ( $<20 \mu \mathrm{m}$, the material is completely carried away by the flow).

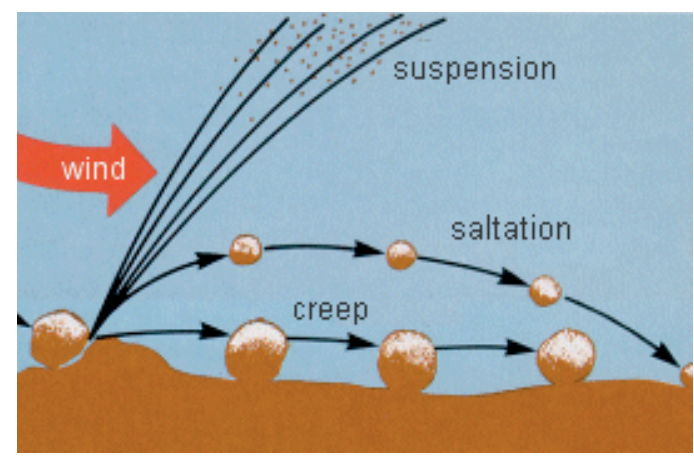

Figure 1. Mechanics of the aeolian transport. Source: NASA (publicly available)

Note that the sediments participating in all three subprocesses, colliding with each other, can either stick together, or break up, or crush other particles, correspondingly changing the characteristics of both transport, while the macroobjects that they form (for example, snowdrifts) affect the entire flow. Complexity, a large number of degrees of freedom of such a system, the natural randomness of the process are all just some of the factors that force researchers to resort to statistical and approximate calculation methods.

A nother important result obtained by $B$ agnold is a formula describing the mass of material that the wind is able to transport in the saltation layer. It is written as:

$$
q=C \frac{\rho}{g} \sqrt{\frac{d}{D}} u_{*}^{3},
$$

where $\mathrm{q}$ is mass of material transported along a unit length; $\mathrm{C}$ is dimensionless constant of the order of one, $\rho$ is air density; $\mathrm{g}$ is acceleration due to gravity; $d$ is reference grain size; $D$ is uniform grain size used by Bagnold in his ex- periments $(250 \mu \mathrm{m}) ; u_{*}$ is friction velocity, which is written as:

$$
u_{*}=\sqrt{\frac{\tau_{w}}{\rho_{a}}},
$$

where $\tau_{w}$ is local shear stress on the wall, $\rho_{a}$ is air density. This value is especially important when simulating snow transport and snow accumulation, its calculation underlies all numerical models of these processes.

The study of snow transport processes was continued by Mellor [9], Izyumov and Davenport [28, 29], K obayashi [30], Iversen [6, 7], A nderson and Huff [1], Gamble [31]. In particular, the latter were engaged in finding out the average path length of particles in the saltation layer: Bagnold gave a value of $9 \mathrm{~m}$ [2], then A nderson and $\mathrm{Huff}$ reduced it to a range of 4-8 $\mathrm{m}$, and Gamble expanded it to 5-10 m.

\section{NUMERICAL MODELLING OF SUSPEN- SION}

Suspension is usually modeled using Eulerian approach [19], al though there is at least one work where the Lagrangian approach was used [16]. M ost likely, this is due to the greater homogeneity of the flow due to the small particle sizes, which allows formulating models in a more applicable way without large losses in accuracy.

Firstly, let us consider the application of the snow density transport equation, exampled by the work of Okaze et al. [12]. Using two equations in this paper made it possible to differentiate the inputs from falling and drifting flows of snow into the snowdrift forming around a cube.

To describe the distribution of snow density $\Phi$, defined as the mass of snow particles per unit volume, the following differential equation is used:

$$
\frac{\partial\langle\Phi\rangle}{\partial t}+\frac{\partial\langle\Phi\rangle\left\langle u_{i}\right\rangle}{\partial x_{i}}+\frac{\partial\langle\Phi\rangle\langle w f\rangle}{\partial x_{3}}=\frac{\partial}{\partial x_{i}}\left[\frac{v_{t}}{\sigma_{s}}\left(\frac{\partial\langle\Phi\rangle}{\partial x_{i}}\right)\right],
$$


where uf is snowfall rate, ve is turbulent viscosity, $\sigma_{\mathrm{s}}$ is turbulent Schmidt number. In this case, the snow accumulation process is divided into addition of the falling snow and transport of the already accumulated snow over the surface (angle brackets mean averaging over spatial dimensions and time):

$$
\langle\Phi\rangle=\left\langle\Phi_{s k y}\right\rangle+\left\langle\Phi_{\text {surf }}\right\rangle
$$

Snow deposition per unit of time and unit of area is expressed as $\langle\Phi\rangle_{p}\langle w f\rangle$, where the subscript " $\mathrm{p}^{\prime}$ means calculation within the control volume. The deposition fluxes $(\mathrm{kg} / \mathrm{s})$ for the first and second modes, respectively, are calculated as:

$$
\begin{gathered}
D_{\text {sky }}=-\left\langle\Phi_{\text {sky }}\right\rangle_{p}\left\langle w f_{\text {sky }}\right\rangle \Delta x \Delta y \\
D_{\text {surf }}=-\left\langle\Phi_{\text {surf }}\right\rangle_{p}\left\langle w f_{\text {surf }}\right\rangle \Delta x \Delta y,
\end{gathered}
$$

where $\Delta x \Delta y$ is horizontal platform of the control volume. The erosion flux $(\mathrm{kg} / \mathrm{s})$ of snow on the surface for $u^{*}>u_{t}^{*}$, caused by shear stress is described by the expression:

$$
E_{\text {surf }}=-\frac{\pi \zeta}{6} \rho\left\langle u^{*}\right\rangle\left(1-\frac{\left\langle u_{t}^{*}\right\rangle^{2}}{\left\langle u^{*}\right\rangle^{2}}\right) \Delta x \Delta y
$$

where $\zeta$ is a dimensionless coefficient that roughly equals $10^{-3}$.

The net deposition rate on the bottom surface of the control volume as a result of all processes is given by:
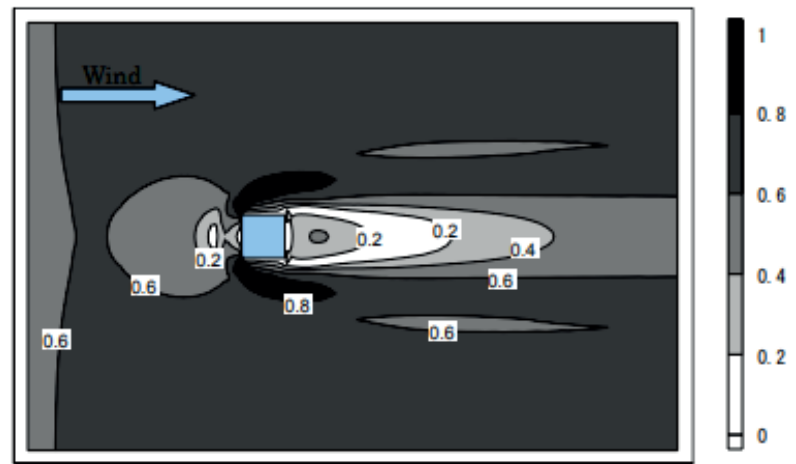

a) Scalar normalized velocity at $z=0.025 \mathrm{H}$

$$
M_{\text {total }}=D_{\text {sky }}+D_{\text {surf }}+E_{\text {surf }}
$$

and the variation of snow depth per unit of time takes the form:

$$
\Delta z_{s}=\frac{M_{\text {total }}}{\rho_{s} \Delta x \Delta y}
$$

where $\rho_{\mathrm{s}}$ is accumulated snow density.

Also, on the surface where snow deposit is forming, a boundary condition is set, which states that the change in snow density is determined by erosion:

$$
\left.\frac{v_{t}}{\sigma_{s}}\left(\frac{\partial\left\langle\Phi_{\text {surf }}\right\rangle}{\partial x_{3}}\right)\right|_{\text {surf }}=\frac{E_{\text {surf }}}{\Delta x \Delta y}
$$

The contribution to snow deposition by transport fluxes on the surface is described by the expression:

$$
R_{\text {surf }}=\frac{D_{\text {surf }}+E_{\text {surf }}}{D_{\text {sky }}+D_{\text {surf }}+E_{\text {surf }}}
$$

The following are illustrations of the results obtained using this method (Fig. 2). The resulting forms of snowdrifts are in agreement with those obtained in the experiment or during field observation.

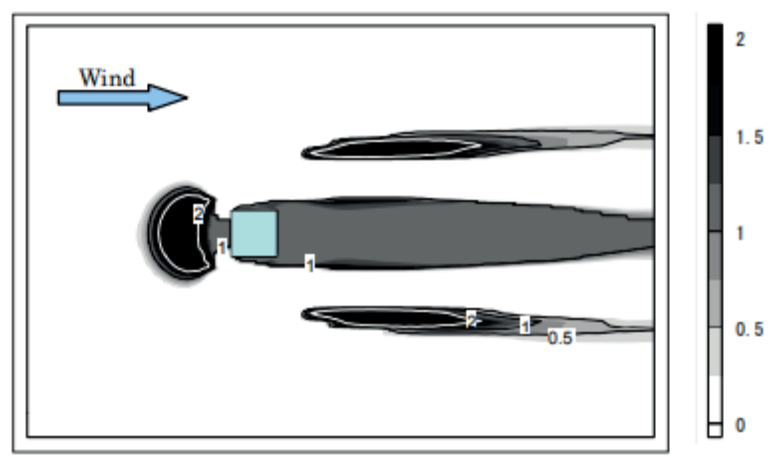

b) Horizontal distribution of normalized snow depth 


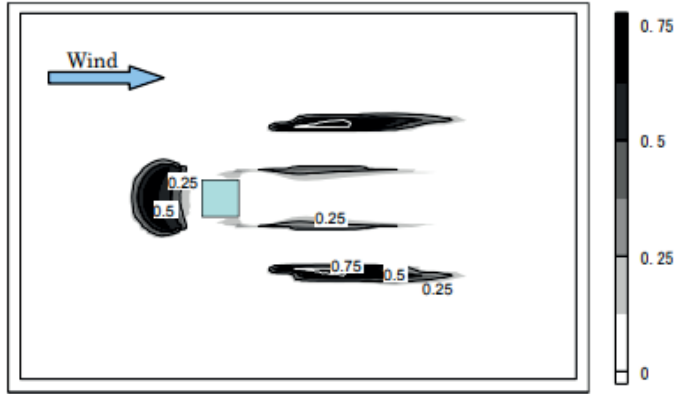

c) Contribution of snow particles from surface to snowdrift, $R_{\text {surf }}$

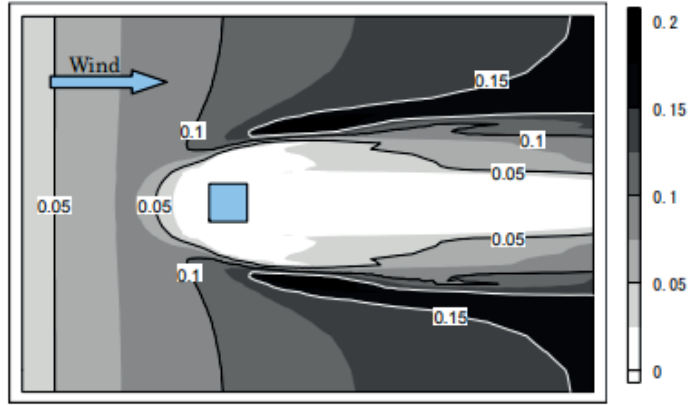

d) Horizontal distribution of density $\Phi_{\text {surf }}$ of snow particles coming from the surface at $\mathrm{z}=0.025 \mathrm{H}$

Figure 2. Results obtained by 0 kaze et al. using the equation of snow density transport to model the suspended layer

Secondly, let us consider the application of the snow volume fraction transport equation, exampled by the work of Sundsbø [17]. Snow volume fraction $f$ in a control volume can be obtained from the expression for the density of the twophase flow $\rho$ m:

$$
\rho_{m}=f \rho_{\text {snow }}+(1-f) \rho_{\text {air }}
$$

To describe the suspension, the convectiondiffusion equation is used:

$$
\frac{\partial f}{\partial t}+\frac{\partial}{\partial x}(f u)+\frac{\partial}{\partial z}(f w)=\frac{\partial}{\partial x}\left(c_{t} v_{t} \frac{\partial f}{\partial x}\right)+\frac{\partial}{\partial z}\left(c_{t} v_{t} \frac{\partial f}{\partial z}\right)-\frac{\partial}{\partial z}\left(f w_{\text {sus }}\right),
$$

where $u$ and $w$ are wind speeds in directions $x$ and $z$, respectively, $v t$ is turbulent viscosity, $c_{t}$ is diffusion constant, and $w_{\text {sus }}$ is drift velocity between air and snow in suspension, which is assumed to be inversely proportional to turbulence in an air flow:

$$
w_{\text {sus }}=0.3 \frac{\mu}{\mu+\mu_{t}}
$$

Here $\mu$ and $\mu$ tare laminar and turbulent dynamic viscosities, respectively. It is implied that laminar flow conditions give the highest snow settling rate, which can be considered as the limiting volumetric velocity for suspended snow particles (in the work under discussion, its value is taken as $0.3 \mathrm{~m} / \mathrm{s}$ ).

The formulation of the equation for snow transport in the saltation area is also given by: $\frac{\partial f}{\partial t}+\frac{\partial}{\partial x}(f u)+\frac{\partial}{\partial z}(f w)=-\frac{\partial}{\partial z}\left(f w_{\mathrm{sal}}\right)$

where, similarly to the equation (14), $\mathrm{w}_{\text {sal }}$ is drift velocity between air and snow in the saltation layer. Two expressions are proposed to describe its two "modes", which are settling of snow and accumulation of snow. The expressions for both modes are given by:

$$
\begin{gathered}
w_{\text {sal }}=w_{\text {set }}=c_{f}(1-f) f \frac{\nabla p}{\rho_{m}} \\
w_{\text {sal }}=w_{\text {acc }}=0.5\left(u_{*}^{3}-u_{* t}^{3}\right) / u_{* t}^{3}
\end{gathered}
$$

where $\nabla p$ is pressure gradient, $c f$ is reciprocal drag coefficient between air and snow, in this work taken as $0.06 \mathrm{~s} / \mathrm{m}$ on based on simulation tests. Both expressions apply for $u^{*}>u_{t}^{*}$. 


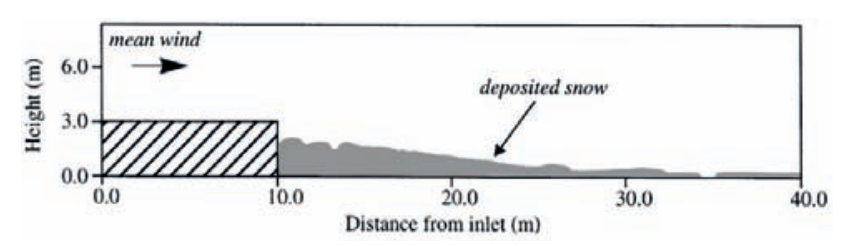

a) Snow accumulation on the side of a building without the use of a deflector.

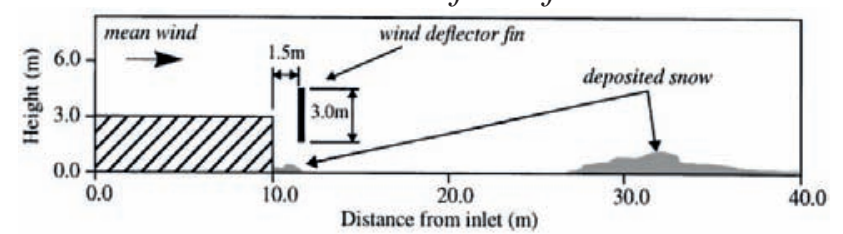

b) Snow accumulation at the side of a building using a deflector

Figure 3. Results obtained by Sundsbø using the snow volume fraction trasport equation

to simulate the suspended layer
The described model was used to study the snow accumulation on the side of a building and the use of a reflector to minimize snow formation in this area. Its application made it possible to visualize the difference in the obtained snow distributions.

Finally, let us consider the application of the particles concentration transport equation used in the works of Moore et al. [10] and Naaim et al. [11]. In the latter work the snow transport was both the saltation and the suspension were modeled. The differential equation for the first process is given by:

$$
\frac{\partial \bar{C}}{\partial t}+\frac{\partial \bar{C}\left(u_{i}-U_{F_{i}}\right)}{\partial x_{i}}=\frac{\partial}{\partial x_{i}}\left(\frac{v_{t}}{\sigma_{S}} \frac{\partial \bar{C}}{\partial x_{i}}\right)+\vec{e}_{i} \iint_{S} \varphi_{S} \vec{n} \mathrm{~d} S
$$

where $\bar{C}$ is average concentration of particles in a control volume, $U_{F_{i}}$ is snowfall speed in the ith direction, $\varphi_{s}$ is mass flux between the suspension and saltation layers. The equation for the second process looks similar:

$$
\frac{\partial \bar{C}_{S}}{\partial t}+\frac{\partial \bar{C}_{s} u_{i}}{\partial x_{i}}=\vec{e}_{i} \iint_{S}\left(\varphi_{g}+\varphi_{S}\right) \vec{n} \mathrm{~d} S
$$

Here $\varphi_{g}$ is mass flux between the air flow and the surface, which will be discussed below.

\section{NUMERICAL MODELLING OF SALTA- TION}

A mong the methods for modelling snow in the saltation layer, the most frequently used are the mass transport models formulated by Iversen et al., Pomeroy and Gray, and the erosiondeposition model formulated by Naaim et al. L et us consider them sequentially.
In the papers of Iversen et al. $[6,7]$, one of the first numerical models for three-dimensional calculation of snow transport was suggested, with saltation and suspension both taken into account. Later it was implemented by U ematsu et al. [20]. In the proposed methodology, the calculations are carried out in three stages. First, the air flow field is calculated using the RANS turbulence model, then the obtained data is used to calculate the density of the snow flow, and, finally, the snow transport rate is calculated by counting the snow particles that were not transported by saltation. Creep is not taken into account in this model.

The mass transported by saltation is modeled by the classical formula given by Pomeroy and Gray [13]:

$$
q=C \frac{\rho}{g} \frac{w_{f}}{u_{* t}} u_{*}^{2}\left(u_{* t}-u_{*}\right)
$$

where all quantities correspond to those in the formula (1), and $\mathrm{w} f$ is average snowfall rate.

Saltation was modeled by the diffusion equation: 


$$
\frac{\partial \Phi}{\partial t}+\nabla\left(\Phi u_{s}\right)=\left(K_{s} \frac{\partial \Phi}{\partial x}\right)+\left(K_{s} \frac{\partial \Phi}{\partial y}\right)+\frac{\partial}{\partial x}\left(K_{s} \frac{\partial \Phi}{\partial z}\right)-\frac{\partial\left(w_{f} \Phi\right)}{\partial z}
$$

where $\Phi$ is snow transport density, us is particle transport rate, $K_{s}$ is vortex diffusion coefficient of snow transport density.

The snow deposition rate is calculated using the formula:

$$
d=\left|w_{f}\right| \Phi_{h}
$$

where $\Phi_{\mathrm{h}}$ is density of snow transport in the saltation layer of thickness $h$.

The expression for the ablation rate has the form:

$$
e=\frac{q\left|w_{f}\right|}{u_{h} h}
$$

where $u_{h}$ is particle transport rate in the saltation layer.

Finally, the snow transport rate, defined as the mass of snow accumulating on a unit area per unit of time, is written as follows:

$$
\begin{aligned}
& s=-(d+e) \\
& \frac{\partial \bar{C}}{\partial t}+\bar{u} \frac{\partial \bar{C}}{\partial x}+\left(v-\left|w_{f}\right|\right) \frac{\partial \bar{C}}{\partial y}=\frac{\partial}{\partial x}\left(\frac{v_{t}}{\sigma_{s}} \frac{\partial \bar{C}}{\partial x}\right)+\frac{\partial}{\partial y}\left(\frac{v_{t}}{\sigma_{s}} \frac{\partial \bar{C}}{\partial y}\right)
\end{aligned}
$$

Formulas (20) - (24) were used in four calculations of snow transport: near a snow fence, around a cube (Fig. 4), near a wind catcher, and around a hill. The results obtained were consistent with experiments and field observations. With this model, though, only the snow transport rate can be calculated, but not the change in snow depth. The authors point out that this problem should be considered in more detail

The work of Liston et al. [8] was aimed at improving the model used by U ematsu et al. The case was considered in which the wind speed is low enough to neglect the transport of particles from the saltation layer to the turbulent flow layer described by one part of the model, while the second part describes the process of transporting their mass into the layer of accumulating snow. The flow is resolved through the time-averaged 2D NavierStokes equations using the $\mathrm{k}-\varepsilon$ turbulence model in conjunction with the saltation model to compute snow accumulation over time near the snow fence. The two-dimensional equation of mass accumulation in a turbulent layer has the form:

where vt is turbulent viscosity coefficient, $\bar{C}$ is particle concentration in density units, $\sigma_{s}$ is turbulent Schmidt number. The concentration at the bottom of the suspended layer is equal to the average concentration in the saltation layer.

The change in the height of the snow cover $h$ is written as follows:

$$
\frac{\partial h(x, t)}{\partial t}+\frac{1}{\gamma}+\partial\left(\frac{Q_{t}(x, t)+Q_{s}(x, t)}{\partial x}\right)=0
$$

where $\gamma$ is bulk density of snow, $Q_{t}$ is mass transport flux in a suspended bed, $Q_{s}$ is mass transport flux in the sal tation layer.

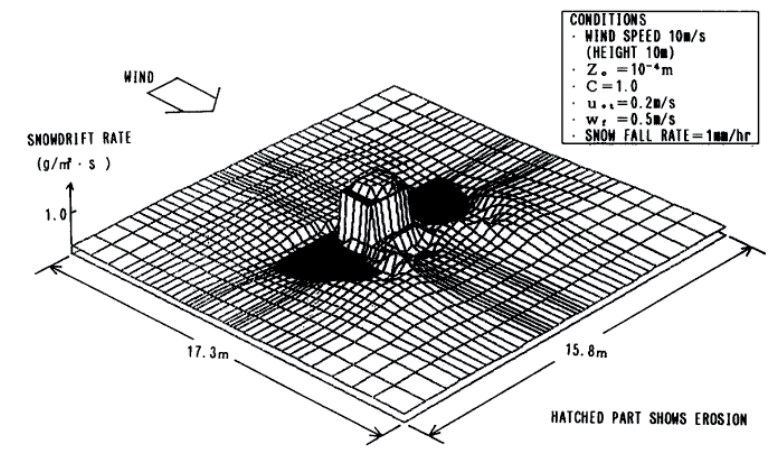

Figure 4. Results obtained by U ematsu et al. for snow accumulation around a hut using the mass transport model of I versen et al. to model the saltation layer 
Snow deposition is calculated on the assumption that accumulation occurs when the shear velocity of the flow falls below threshold friction velocity. The control volumes are filled gradually, and the mesh is rebuilt as they are accumulating. Since it is assumed that $\mathrm{Q}_{\mathrm{s}}$ responds instantly to changes in friction velocity, the inertia of erosion and deposition is not taken into account. The model makes it possible to calculate the equilibrium snow deposition, but does not make it possible to estimate the time required for the formation of a snow layer of a given thickness [11].

L et us move on to the mass transport equation formulated by Pomeroy and Gray. In their works [13, 14], the details of snow transport (accumulation and redistribution), snow melting, interaction of melt water with frozen layers and their influence on the descent of snow masses in dangerous regions were investigated. The authors developed physical models to describe these processes and applied them to the description of snow formation in the Canadian province of Saskatchewan. The obtained equation of mass transport indicates an almost linear acceleration of this process with an increase in the friction velocity, which is in agreement with field observations. As with similar models, the equation is sensitive to the cohesion of the snow layer, which is determined by the boundary friction velocity. The authors also showed that generally the direction of the annual snow transport in saltation layer does not always coincide with the direction of the wind.

The flow of a mass of snow having an average weight $W_{p}$ and saltating at an average speed $u_{p}$, is written as follows:

$$
Q_{\text {salt }}=\frac{u_{p} W_{p}}{g}
$$

The authors propose the following expression for $W_{p}$ :

$$
W_{p}=e\left(\tau-\tau_{n}-\tau_{t}\right)
$$

where $\tau$ is atmospheric shear stress, $\tau_{n}$ and $\tau_{t}$ are shear stress on non-destructible and destructible surfaces, respectively. The coefficient eis dimensionless and means the "efficiency" of saltation. It is inversely proportional to the kinetic friction arising in the process of collision and separation of particles against the surface. Formula for $u_{p}$ is given by:

$$
u_{p}=c u_{* t}
$$

where $c$ is a constant parameter and $u_{* t}$ is threshold friction velocity that separates the processes of erosion and deposition.

Substituting (28) and (29) into (27), we obtain a general expression for the saltation layer:

$$
Q_{\text {salt }}=\frac{c e \rho}{g} u_{* t}\left(u_{*}^{2}-u_{* n}^{2}-u_{* t}^{2}\right)
$$

Determining the values of the coefficients from the experimental data, the authors give the final form of the expression:

$$
Q_{\text {salt }}=\frac{0.68 \rho}{u_{*} g} u_{* t}\left(u_{*}^{2}-u_{* n}^{2}-u_{* t}^{2}\right)
$$

It is shown that, in contrast to the result obtained by Bagnold for sand, the snow flux is a quadratic function of the friction velocity, not a cubic one. The authors point out that this is a consequence of the presence of an average horizontal speed, which does not affect the wind speed in general, and efficiency, which grows reciprocally to the wind speed. It is also noted that saltation models for sand are poorly applicable to snow transport just because of the materials they describe. Grains of sand are separate, non-sticking particles, while snowflakes are crystals that can break up or stick together.

Finally, let us consider the latest and most commonly used way to describe the saltation layer, the erosion-deposition model. It is based on the work of A nderson and Huff [1], who proposed a model of aeolian transport of sand deposits for the case when particles of 
the size of sand grains are subject to saltation. It consists of four parts that describe a) aerodynamic entrainment; b) trajectories of grains of sand; c) interaction of particles with the surface; d) influence on the impulse from the wind. Each submodel is responsible for a specific part of the process and is supported by experimental data to refine the values of some constants. Together the parts make it possible to calculate aeolian saltation from the moment of sediment capture by aerodynamic entrainment until the transition to a stationary state. The authors show the important role of long, high-energy trajectories: despite the predominance of short trajectories with low energies in the saltation zone, it is the collisions of sediments with the surface that determine the response of the entire system to changes in wind velocity due to knocking new particles out of the surface. A form of the "splash" function is proposed to take such jumps into account, which can last as long as a few seconds. An accurate calculation of fluctuations in wind velocity allows establishing its relationship with the stationary mass flow in the form of a power function of the shear velocity. This model, in contrast to the previous one, takes into account inertia, but the "splash" function is not suitable for snow in the form given by the authors and requires modification [11]. U sing these results, Naaim et al. [11] formulated a model that has been used by researchers from different countries almost unchanged for about quarter of a century. Pointing out the shortcomings in the models developed by Iversen et al. and Liston et al., as well as the limitations that do not allow direct use of the Anderson and Huff model, the team of authors proposed their own version of the erosiondeposition model, in which they tried to level out the failures of their colleagues. O mitting the details of the derivation of the flow equations, described in detail in the article, let us turn our attention to the modelling of snow transport.
For the mass exchange flux between air and snow layer, the following expression is proposed, similar to (24):

$$
q_{g}=q_{+}-q_{-}
$$

The erosion flow is written as:

$$
q_{-}=A \rho_{a}\left(u_{*}^{2}-u_{* t}^{2}\right)
$$

where $A$ is coefficient that depends on the degree of cohesion in the surface layer and $\rho_{a}$ is air density.

The deposition flow is given by:

$$
q_{+}=\bar{C} w_{f}\left(1-\frac{u_{*}^{2}}{u_{* t}^{2}}\right)
$$

where all quantities correspond to those in the previous formulae.

A t each step of the simulation, expression (2) is recalculated for the flow in each cell of the boundary layer and then compared with the value ut. The snow deposition process is governed by the following conditions:

\begin{tabular}{|l|l|}
\hline$u_{*}<u_{t}$ & Deposition: $q_{g}=q_{+}$ \\
\hline$u_{*}=u_{t}$ & Unchanged: $q_{g}=0$ \\
\hline$u_{*}>u_{t}$ & Erosion: $q_{g}=-q_{-}$ \\
\hline
\end{tabular}

The change in the height of the snow layer is described by an expression similar to (26):

$$
\frac{\partial h}{\partial t}=\frac{q g}{\gamma}
$$

This model was applied to the problem of a flow around a solid snow fence (see Fig. 5). In their work, the authors note that the expression for the erosion flux must be revised and improved despite the quality of results obtained using the model, which are in agree- 
ment with the experiment. This will require new field observations or development of a "splash" function for snow with different properties. They also neglected the movement of particles due to creep and took into account only those particles that were carried by aerodynamic forces.

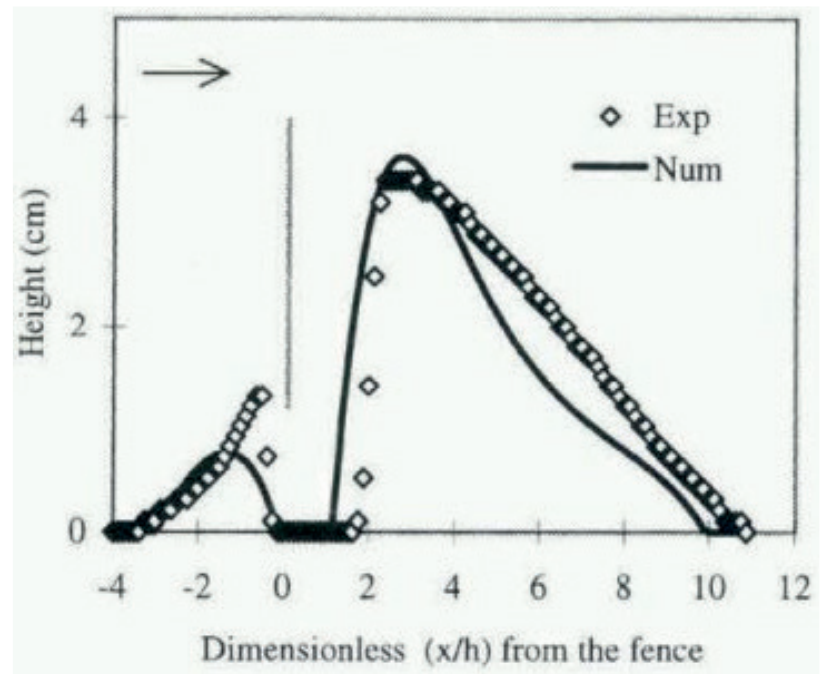

a) $u_{*}=0.23 \mathrm{~m} / \mathrm{s}, u_{* t}=0.21 \mathrm{~m} / \mathrm{s}$

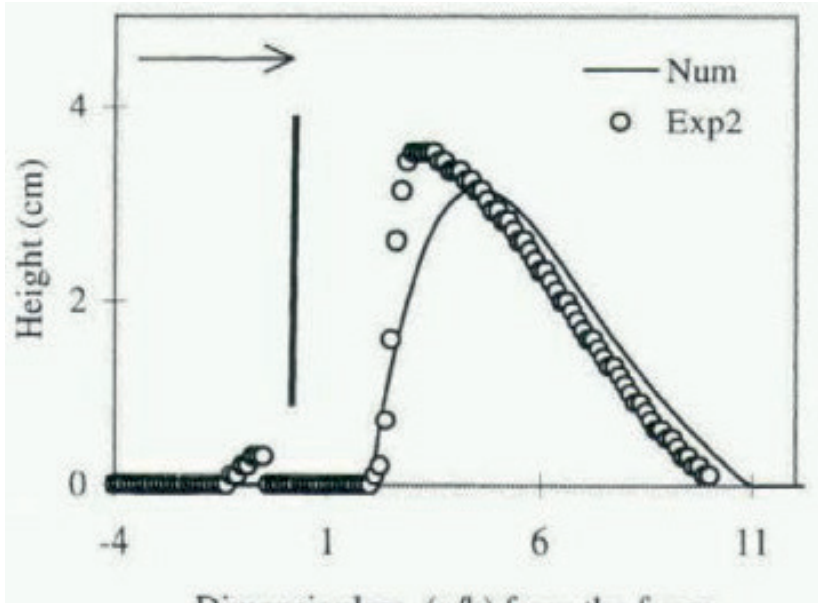

Dimensionless $(\mathrm{x} / \mathrm{h})$ from the fence

b) $u_{*}=0.25 \mathrm{~m} / \mathrm{s}, u_{* t}=0.21 \mathrm{~m} / \mathrm{s}$

Figure 5. Comparison of the results of modelling a snowdrift behind a solid fence with experimental data [43]

\section{ALTERNATIVE METHODS}

A mong the most modern CFD methods is the use of neural networks that do not directly solve the Navier-Stokes equations, but simulate their solution, learning from a dataset of flow behaviors. Such an approach allows obtaining sufficiently plausible results, spending orders of magnitude less computing power and physical time, since with classical CFD each problem needs to be computed from the scratch, but a neural network is only required to be trained once.

Sanchez-Gonzalez et al. [15] developed a framework, which they call "graph networkbased simulators" (GNS). Physical systems are represented by sets of interacting particles, the dynamics of which are described by graphs. Fig. 6 shows how the algorithm works. The simulator $\mathrm{s}_{\theta}$ transforms the initial state $X^{t_{0}}$ into the state $\tilde{X}^{t_{K}}$ by iteratively applying the trained dynamic model $d_{\theta}$ (a) according to the "encoder-processor-decoder" scheme (b): first, the input state $X$ is expressed by a graph $G^{0}$ (c), then $M$ signal transmissions between its nodes are performed, generating graphs $G^{1} \ldots G^{M}(\mathrm{~d})$, and finally dynamic information $Y(e)$ is extracted from the graph $G^{M}$.

This framew ork allows simulating many materials, from viscous substances (a) to water (b) and sand (c), as well as their interaction with solid obstacles (d). The model can also be trained on several materials at once (e). A pretrained model can also handle some cases that it wasn't trained on, like high turbulence flows (f), objects of unknown shape $(g)$, and much more complex design cases compared to the samples (h). In Fig. 9, the top row shows the initial states, the middle row shows the model predictions, and the bottom row shows the results of CFD calculations. 
(a) $\quad X^{t_{0}}$
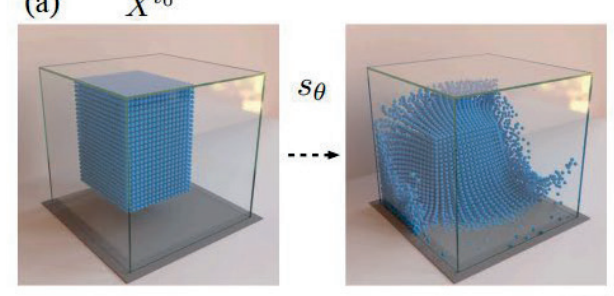

Learned simulator, $s_{\theta}$
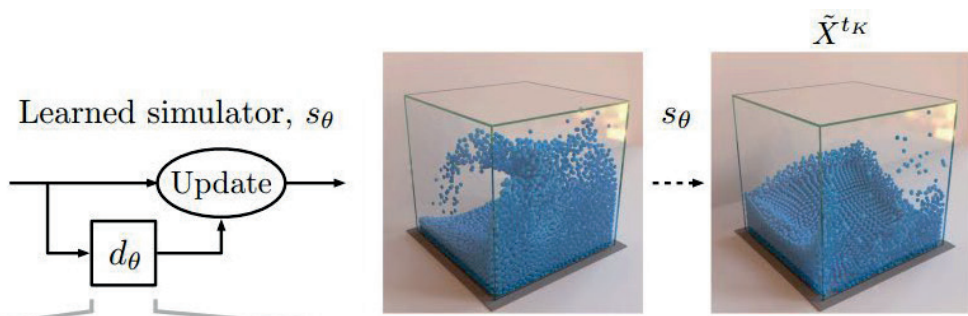

(b)
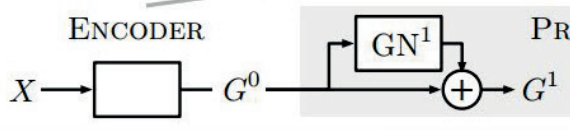

PROCESSOR

(d)

Pass messages

(c) Construct graph
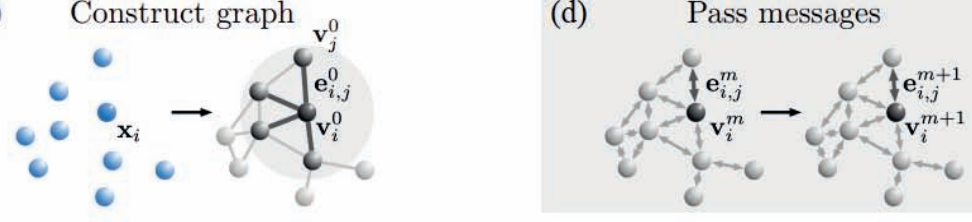

DECODER

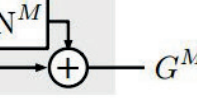

(e) Extract dynamics info

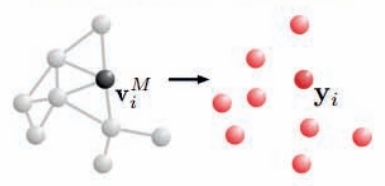

Figure 6. Scheme of the GNS framework

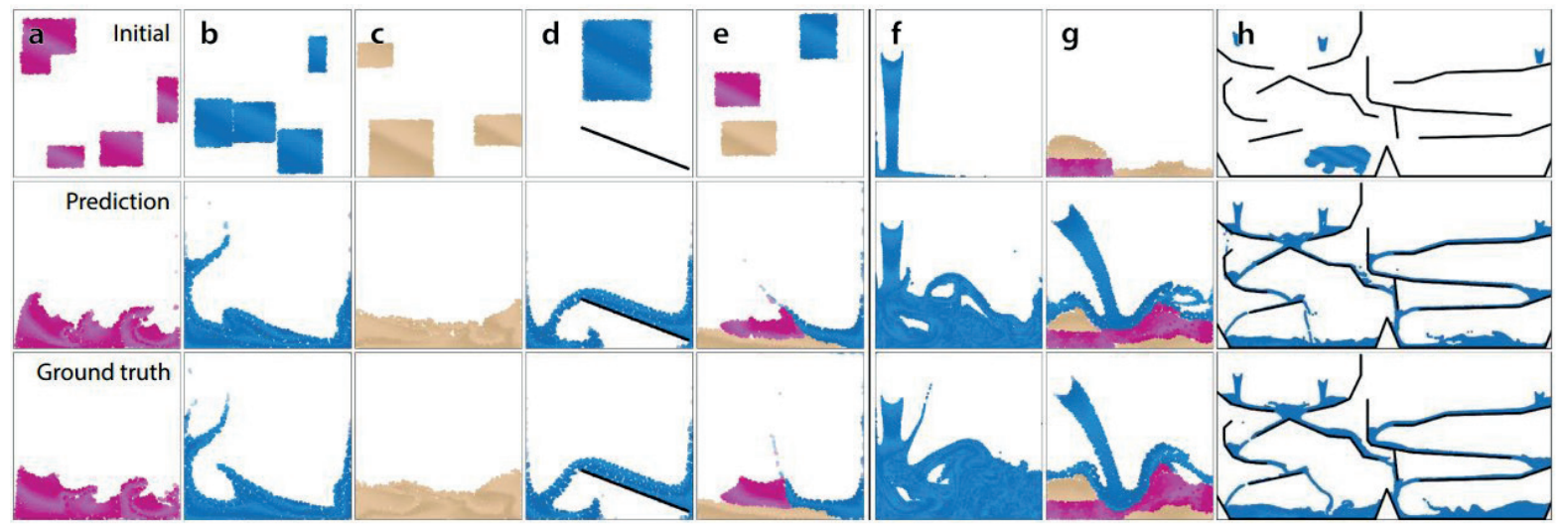

Figure 7. Examples of flow behaviors obtained using the GNS framework for various substances: pink indicates a viscous substance, blue indicates a liquid one, and beige indicates sand

A nother promising "fast" alternative method is replacing the Navier-Stokes equations with a system of lattice Boltzmann equations (LBM). In this case, the fluid flow is perceived as a collection of particles on a spatial grid. The LBM algorithm is characterized by a simpler implementation, higher efficiency in parallelization, and it is better suited for more complex boundary conditions. The team [18] has developed a model of snow transport, which does not yet take into account the influence of snow on the air, but already gives quite plausible distributions of snow.
The numerical lattice Boltzmann equation is a prognostic equation for the distribution function of particles in the i-th direction, $\mathrm{fi}_{\mathrm{i}}$ which is given by:

$f_{i}\left(\boldsymbol{r}+\boldsymbol{c}_{i}+\Delta t, t+\Delta t\right)=f_{i}(\boldsymbol{r}, t)+\Omega_{i} \Delta t$,

where $\mathbf{r}$ is particle direction vector, $\mathbf{c}$ is particle velocity vector, $\Delta \mathrm{t}$ is time step, $\Omega_{\mathrm{i}}$ is interparticle interaction, which is described using the Bhatnagar-Gross-K rook approximation, replacing it with the relaxation of the equilibrium state of the distribution function: 


$$
\Omega_{i}=-\frac{1}{\tau}\left(f_{i}-\hat{f}_{i}\right)
$$

where $\tau$ is relaxation time as a function of kinematic viscosity $v$ :

$$
\tau=\frac{1}{2}+\frac{3 v}{c^{2} \Delta t}
$$

and $\hat{f}_{i}$ is equilibrium distribution function of particles in the i-th direction.

The equation of motion of snow particles is given by:

$$
\frac{d \boldsymbol{u}_{\boldsymbol{p}}}{d t}=-\frac{3}{4}\left(\frac{\rho_{a}}{\rho_{p} d}\right) C_{d} V_{R}\left(\boldsymbol{u}_{\boldsymbol{p}}-\boldsymbol{u}\right)-g \boldsymbol{k},
$$

where $\boldsymbol{u}_{\boldsymbol{p}}$ is particle velocity vector, $\boldsymbol{u}$ is wind speed vector, $V_{R}=\left|\boldsymbol{u}_{\boldsymbol{p}}-\boldsymbol{u}\right|, \mathrm{g}$ is acceleration due to gravity, $\rho$ a and $\rho$ p are air density (1.34 $\left.\mathrm{kg} / \mathrm{m}^{3}\right)$ and particle density $\left(910 \mathrm{~kg} / \mathrm{m}^{3}\right)$, respectively, $d$ is particle diameter $(100 \mu \mathrm{m})$, and $C_{d}$ is drag coefficient of a particle, equal to

$$
C_{d}=\frac{24 v_{0}}{V_{R} d}+\frac{6}{1+V_{R} d / v_{0}}+0.4
$$

where $v_{0}$ is viscosity, equal to $10^{-5} \mathrm{~m}^{2} \mathrm{~s}^{-1}$. The results obtained by the authors are shown in Fig. 8-9.

(a) $\mathrm{t}=8 \mathrm{~s}$

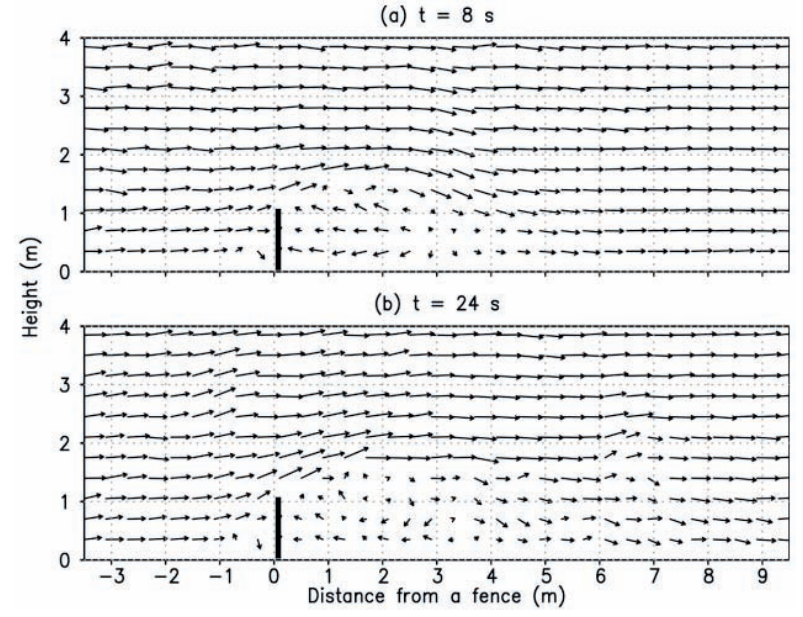

a) (a) $\mathrm{t}=8 \mathrm{~s}$

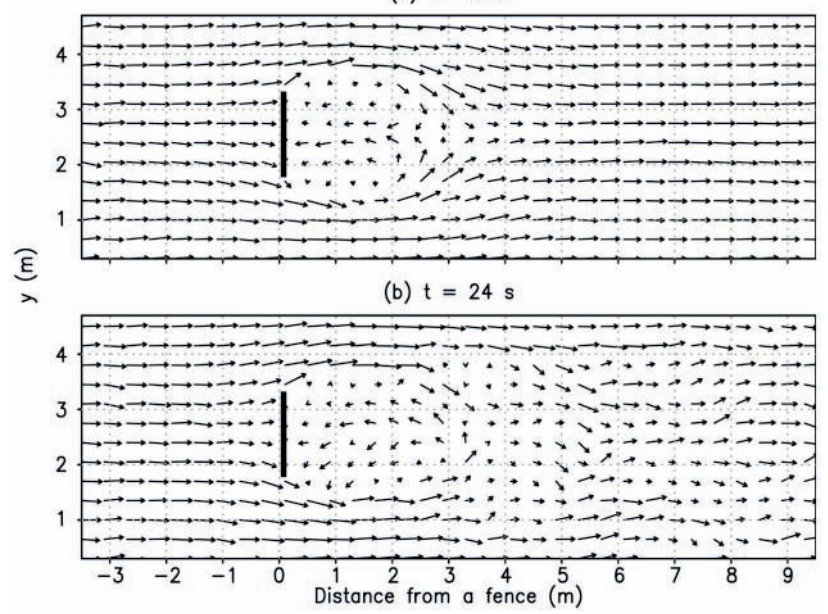

b)

Figure 8. Solution of lattice Boltzmann equations (LBM). Vector field of wind velocity in vertical (a) and horizontal ( $b, z=0.5 \mathrm{~m}$ ) crosssections for three-dimensional flow around a solid fence.
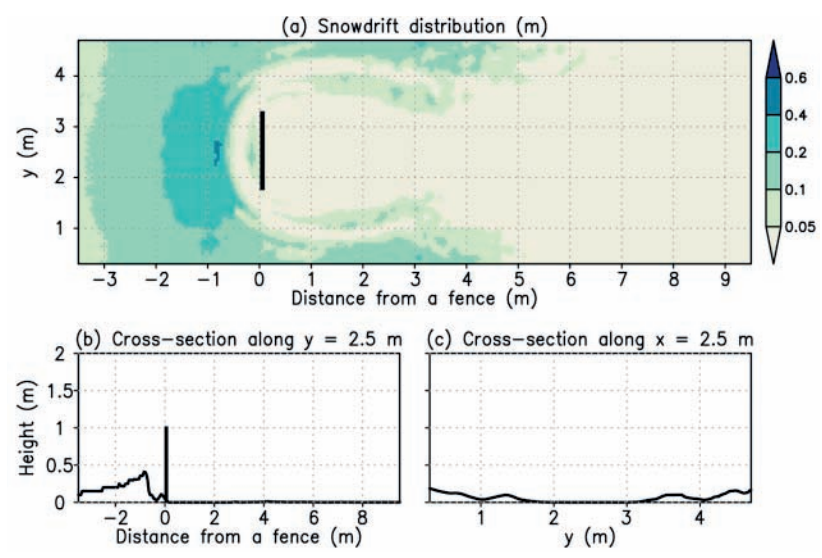

Figure 9. Solution lattice Boltzmann equations (LBM ). Contours of the obtained snow layer (a), vertical cross-sections along the $x$-axis (b) and $y$-axis (c) for a three-dimensional flow around a solid fence

\section{CONCLUSIONS}

This paper provides an overview of various methods of numerical modelling of snow accumulation, primarily based on foreign 
scientific publications and regulatory documents. The methods themselves, as well as the limits of their applicability, the experimental data they were calibrated on and/or verified with, are reviewed in detail. Both "classical" methods and modern "alternative" ones are reviewed. Due to the fact that Russian regulatory documents still do not allow the use of numerical modelling of snow accumulation (despite almost half a century of work in this field by scientists from all over the world), it was impossible to carry out a comparative analysis of foreign methods with Russian ones, since original, non-compilatory scientific works in the field do not yet exist.

It is shown that, taking into account: a) the experience of the worldwide scientific and engineering communities and a variety of approaches to numerical modelling of snow accumulation on roofs of buildings and structures; b) the complexity of the subject, which itself dictates this variety; it is impossible to cover the entire range of sample cases and situations using only a limited set of simple schemes from SP and experimental methods. Further rejection of the methods of numerical and physical modelling, which are recognized and applied by the world community, casts serious doubt on the legitimacy of the recommendations being developed and carries significant risks for the mechanical safety of unique buildings and structures with arbitrary geometry. The inclusion of numerical modelling is necessary to form a modern and flexible regulatory framework, which could be used by engineers to solve much more complex design problems than it is possible now. This requires:

1) Modern research, both foreign and domestic, with the latter taking into account specific features of current construction practices and focused on requests from the industry. Also, possibly additional theoretical and practical developments, new or refined methods for modelling snow accumulation.

2) Development, verification and approbation of numerical methods, carried out using appropriate experimental equipment and in the field, that would allow using all the necessary data (climatic, meteorological, etc.) in numerical models for maximum efficiency.

Only a complex and comprehensive approach to the implementation of technologies for numerical modelling of snow accumulations in modern construction practice will provide the required level of technical support for unique buildings and structures with arbitrary geometry and guarantee the safety of their construction.

\section{ACKNOWLEDGMENTS}

This work was financially supported by the $M$ inistry of Science and Higher Education of the Russian Federation (Project: Theoretical and experimental design of new composite materials to ensure safety during the operation of buildings and structures under conditions of technogenic and biogenic threats \#FW G-2020-0007)

\section{REFERENCES}

1. Anderson, R. S., \& Haff, P. K. (1991). $W$ ind modification and bed response during saltation of sand in air. In A eolian Grain Transport 1 (pp. 21-51). Springer, V ienna.

2. Bagnold, R. A. (1937). The transport of sand by wind. The Geographical Journal, 89(5), 409-438.

3. Bagnold, R.A., (1941). The Physics of Blown Sand and Desert Dunes. M ethuen $\&$ Co.: William M orrow, New Y ork.

4. Beyers, J. H. M., Sundsbø, P. A., \& Harms, T. M. (2004). Numerical simulation of three-dimensional, transient snow drifting around a cube. Journal of Wind Engineering and Industrial Aerodynamics, 92(9), 725-747.

5. Eurocode 1: A ctions on structures - Part 13: General actions - Snow loads. 
6. Iversen, J. D. (1979). D rifting snow similitude. Journal of the hydraulics division, 105(6), 737-753.

7. Iversen, J. D. (1980). Drifting-snow similitude- transport-rate and roughness modeling. J ournal of glaciology, 26(94), 393-403.

8. Liston, G . E., Brown, R. L ., \& Dent, J . D. (1993). A two-dimensional computational model of turbulent atmospheric surface flows with drifting snow. A nnals of Glaciology, 18, 281-286.

9. Mellor, M. (1977). Engineering properties of snow. J ournal of Glaciology, 19(81), 1566.

10. Moore, I., Mobbs, S. D., Ingham, D. B., \& King, J. C. (1994). A numerical model of blowing snow around an Antarctic building. A nnals of Glaciology, 20, 341-346.

11. Naaim, M., Naaim-Bouvet, $F_{\text {., } \& \text { Mar- }}$ tinez, H. (1998). Numerical simulation of drifting snow: erosion and deposition models. A nnals of glaciology, 26, 191-196.

12. O kaze, T., M ochida, A., Tominaga, $Y$., Ito, Y., \& Yoshino, H. (2010). CFD prediction of snowdrift around a cube using two transport equations for drifting snow density. In The Fifth International Symposium on Computational Wind Engineering (CWE2010).

13. Gray, D. M., Pomeroy, J. W., \& Granger, R. J. (1989). M odelling snow transport, snowmelt and meltwater infiltration in open, northern regions. Northern Lakes and Rivers, 22, 8-22.

14. Pomeroy, J. W., \& G ray, D. M. (1990). Saltation of snow. Water resources research, 26(7), 1583-1594.

15. Sanchez-G onzalez, A., G odwin, J., Pfaff, T., Y ing, R ., Leskovec, J ., \& Battaglia, P. (2020, November). Learning to simulate complex physics with graph networks. In International Conference on Machine Learning (pp. 8459-8468). PM LR.

16. Serine, A., Shimura, M., Maruoka, A., \& Hirano, H. (1999). The numerical simulation of snowdrift around a building. Interna- tional Journal of Computational Fluid Dynamics, 12(3-4), 249-255.

17. Sundsbø, P. A. (1998). Numerical simulations of wind deflection fins to control snow accumulation in building steps. Journal of Wind Engineering and Industrial A erodynamics, 74, 543-552.

18. Tanji, S., Inatsu, M ., \& O kaze, T. (2021). Development of a snowdrift model with the lattice Boltzmann method. Progress in Earth and Planetary Science, 8(1), 1-16.

19. Tominaga, Y. (2018). Computational fluid dynamics simulation of snowdrift around buildings: Past achievements and future perspectives. Cold Regions Science and Technology, 150, 2-14.

20. Uematsu, T., Nakata, T., Takeuchi, K., Arisawa, Y ., \& K aneda, Y. (1991). Threedimensional numerical simulation of snowdrift. Cold regions science and technology, 20(1), 65-73.

21. Kind, R. J. (1990). Mechanics of aeolian transport of snow and sand. Journal of Wind Engineering and Industrial Aerodynamics, 36, 855-866.

22. Thiis, T. K., \& Ramberg, J. F. (2008). $M$ easurements and numerical simulations of development of snow drifts of curved roofs. Proceedings of the Snow Engineering VI, Whistler, BC, Canada, 21-27.

23. Wang, J., Liu, H., Chen, Z., \& Ma, K. (2020). Wind tunnel test of wind-induced snowdrift on stepped flat roofs during snowfall. Natural Hazards, 104(1), 731752.

24. ASCE 7-16 Minimum Design Loads and A ssociated Criteria for Buildings and Other Structures.

25. JSCE - Standard Specifications for Steel and Composite Structures

26. Building Code of RF 20.13330.2016 L oad and actions.

27. Tominaga, Y., Okaze, T., \& M ochida, A. (2011). CFD modeling of snowdrift around a building: An overview of models and evaluation of a new approach. B uilding and Environment, 46(4), 899-910. 
28. Isyumov, N., 1971. An Approach to the Prediction of Snow Loads, PhD. Thesis, University of Western Ontario, London, Canada.

29. Isyumov, N., \& Davenport, A. G . (1974). A probabilistic approach to the prediction of snow loads. Canadian Journal of Civil Engineering, 1(1), 28-49.

30. Kobayashi, D. (1972). Studies of snow transport in low-level drifting snow. Contributions from the Institute of Low Temperature Science, 24, 1-58.

31. G amble, S. L ., Kochanski, W. W., \& Irwin, P. A. (1992). Finite area element snow loading prediction-applications and advancements. Journal of wind engineering and industrial aerodynamics, 42(1-3), 15371548.

32. Beyers, J. H. M., Sundsbø, P. A., \& Harms, T. M. (2004). Numerical simulation of three-dimensional, transient snow drifting around a cube. Journal of Wind Engineering and Industrial A erodynamics, 92(9), 725-747.

33. T ominaga, $Y_{\text {., }}$ M ochida, $A_{\text {., }} \mathbf{Y}$ oshino, $H_{\text {., }}$ Shida, T., \& O kaze, T. (2006, July). CFD prediction of snowdrift around a cubic building model. In The fourth international symposium on computational wind engineering (CW E2006), Y okohama, J apan (pp. 941-944).

34. Thiis, T. K., \& O'Rourke, M. (2015). Model for snow loading on gable roofs. Journal of Structural Engineering, 141(12), 04015051.

35. Tominaga, $Y_{\text {,, }}$ Okaze, T., Mochida, A., 2016. CFD simulation of drift snow loads for an isolated gable-roof building. In: Proceedings of the 8th International Conference on Snow Engineering, Nantes, France, pp. 208-214 (J une 14-17)

36. Kang, L. Y., Zhou, $X . Y_{\text {,, \& Gu, M. }}$ (2016). A new method for predicting snowdrift on flat roofs. In Proceedings of the 8th International Conference on Snow Engineering, Nantes, France, pp. 137-141 (J une 14-17).
37. Zhou, X., Kang, L., Gu, M., Qiu, L., \& Hu, J. (2016). Numerical simulation and wind tunnel test for redistribution of snow on a flat roof. Journal of Wind Engineering and Industrial A erodynamics, 153, 92-105.

38. Thiis, T. K. (2000). A comparison of numerical simulations and full-scale measurements of snowdrifts around buildings. Wind \& structures, 3(2), 73-81.

39. Thiis, T. K . (2003). Large scale studies of development of snowdrifts around buildings. Journal of Wind Engineering and Industrial A erodynamics, 91(6), 829-839.

40. Beyers, M ., \& W aechter, B. (2008). M odeling transient snowdrift development around complex three-dimensional structures. Journal of Wind Engineering and Industrial A erodynamics, 96(10-11), 16031615.

41. Okaze, T., Kato, S., Tominaga, Y., M o-

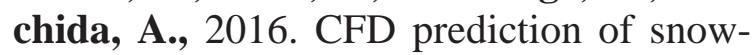
drift in a building array. In: Proceedings of the 8th International Conference on Snow Engineering, Nantes, France, pp. 26-29 (J une 14-17).

42. ASCE/SEI 49-12 Wind Tunnel Testing for Buildings and $O$ ther Structures

43. Takeuchi, M. (1980). Vertical profile and horizontal increase of drift-snow transport. J ournal of Glaciology, 26(94), 481-492.

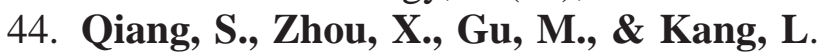
(2021). A novel snow transport model for analytically investigating effects of wind exposure on flat roof snow load due to saltation. Journal of Wind Engineering and Industrial A erodynamics, 210, 104505.

45. Ma, W ., Li, F., Sun, Y ., Li, J ., \& Zhou, X. (2021). Field measurement and numerical simulation of snow deposition on an embankment in snowdrift. Wind and Structures, 32(5), 453-469.

46. ISO 4355-2016 - Bases for design of structures - Determination of snow loads on roofs, IDT.

47. Hitryh, D. P. (2013). Opyt modelirovaniya processov snegoperenosa i snegootlozheniya [Experience in modeling the processes 
of snow transfer and snow deposition]. A NSY S A dvantage, 27 Y 32.

48. Belostocky A. M. i dr. O snegovyh nagruzkah na zdaniya i sooruzheniya [A bout snow loads on buildings and structures] // Vopro-sy prikladnoj matematiki i vychislitel'-noj mekhaniki. - 2017. - P. 212-215.

49. Belostocky A.M., Akimov P.A., Afanas'eva I.N. Vychislitel'naya aerodinamika v zadachah stroitel'stva [Computational aerodynamics in construction probIems]. M ., Izdatel'stvo A SV , 2017, 720 p.

50. Stoyanov, V.V., ZH galli, SH. CHislennoe modelirovanie snegovyh nagruzok na pokrytiyah unikal'nyh i sovremennyh arhitekturnyh form [N umerical modeling of snow loads on coverings of unique and modern architectural forms]. - 2019. - T. 30 (69) No 1 (2).

51. M atveenko, E.V. (2018). Obobshchennyj analiz metodov modelirovaniya snegovoj nagruzki [Generalized analysis of snow load modeling methods]. // Vestnik B restskogo gosudarstvennogo tekhnicheskogo universiteta. - P. 77-80.

52. Belostotsky, A.M., Britikov, N.A., G oryachevsky, O.S. (2021). Comparison of determination of snow loads for roofs in building codes of various countries. International Journal for Computational Civil and Structural Engineering, 17(3), 39-47.

\section{СПИСОК ЛИТЕРАТУРЫ}

1. Anderson R, S., Haff P. K. Wind modification and bed response during saltation of sand in air //A eolian Grain Transport 1. Springer, V ienna, 1991. - C. 21-51.

2. Bagnold R. A. The transport of sand by wind //The Geographical J ournal. - 1937. T. 89. - №. 5. - C. 409-438.

3. Bagnold, R.A., 1941. The Physics of Blown Sand and Desert Dunes. M ethuen $\&$ Co.: William M orrow, New Y ork.
4. Beyers J. H. M., Sundsbø P. A., Harms T. M. Numerical simulation of threedimensional, transient snow drifting around a cube //J ournal of Wind Engineering and Industrial A erodynamics. - 2004. - T. 92. №. 9. - C. 725-747.

5. Eurocode 1: A ctions on structures - Part 13: General actions - Snow loads.

6. Iversen J. D. Drifting snow similitude //J ournal of the hydraulics division. - 1979. - T. 105. - №. 6. - C. 737-753.

7. Iversen J. D. Drifting-snow similitudetransport-rate and roughness modeling //J ournal of glaciology. - 1980. - T. 26. №. 94. - C. 393-403.

8. Liston G . E ,, Brown R. L ,, Dent J . D. A two-dimensional computational model of turbulent atmospheric surface flows with drifting snow //A nnals of Glaciology. 1993. - T. 18. - C. 281-286.

9. Mellor M. Engineering properties of snow I/J ournal of Glaciology. - 1977. - T. 19. №. 81. - C. 15-66.

10. Moore, I., Mobbs, S.D., Ingham, D.B., King, J.C., 1994. A numerical model of blowing snow around an A ntarctic building. Ann. Glaciol. T. 20 (1), C. 341-346.

11. Naaim M., Naaim-Bouvet F., Martinez H. Numerical simulation of drifting snow: erosion and deposition models //A nnals of glaciology. - 1998. - T. 26. - C. 191-196.

12. Okaze T. et al. CFD prediction of snowdrift around a cube using two transport equations for drifting snow density //The Fifth International Symposium on Computational Wind Engineering (CWE2010). 2010.

13. Gray D. M., Pomeroy J. W., G ranger R. J. Modelling snow transport, snowmelt and mel twater infiltration in open, northern regions //N orthern Lakes and Rivers. - 1989. - T. 22. - C. 8-22.

14. Pomeroy, J.W., Gray, D.M., 1990. Saltation of Snow. Wat. Res. Research. T. 26, Ч. 7, C. 1583-1594.

15. Sanchez-Gonzalez A. et al. Learning to simulate complex physics with graph net- 
works //International Conference on $\mathrm{Ma}$ chine Learning. - PM LR, 2020. - C. 84598468.

16. Serine A, et al. The numerical simulation of snowdrift around a building //International Journal of Computational Fluid Dynamics. - 1999. - T. 12. - №. 3-4. - C. 249-255.

17. Sundsbø P. A. Numerical simulations of wind deflection fins to control snow accumulation in building steps //Journal of Wind Engineering and Industrial A erodynamics. - 1998. - T. 74. - C. 543-552.

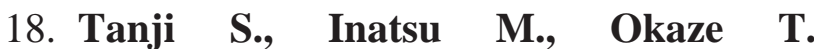
Development of a snowdrift model with the lattice Boltzmann method //Progress in Earth and Planetary Science. - 2021. - T. 8. - №. 1. - C. 1-16.

19. Tominaga $\mathbf{Y}$. Computational fluid dynamics simulation of snowdrift around buildings: Past achievements and future perspectives //Cold Regions Science and Technology. - 2018. - T. 150. - C. 2-14.

20. Uematsu $\mathbf{T}$, et al. Three-dimensional numerical simulation of snowdrift //Cold regions science and technology. - 1991. - T. 20. - №. 1. - C. 65-73.

21. K ind $\mathbf{R} . \mathbf{J}$. M echanics of aeolian transport of snow and sand //J ournal of W ind Engineering and Industrial A erodynamics. 1990. - T. 36. - C. 855-866.

22. Thiis T. K., Ramberg J . F. M easurements and numerical simulations of development of snow drifts of curved roofs //Proceedings of the Snow Engineering VI, W histler, BC, Canada. - 2008. - C. 21-27.

23. Wang J , et al. Wind tunnel test of windinduced snow drift on stepped flat roofs during snowfall //Natural Hazards. - 2020. - T. 104. - №. 1. - C. 731-752.

24. ASCE 7-16 Minimum Design Loads and A ssociated C riteria for Buildings and Other Structures.

25. JSCE - Standard Specifications for Steel and Composite Structures

26. СП 20.13330.2016 Нагрузки и воздействия
27. T ominaga $Y$,, Okaze T., M ochida A. CFD modeling of snowdrift around a building: A $n$ overview of models and evaluation of a new approach //Building and Environment. - 2011. - T. 46. - №. 4. - C. 899-910.

28. Isyumov N. A $n$ approach to the prediction of snow ioads // PhD. Theis, University of W estern Ontario, Canada. - 1971.

29. Isyumov N., Davenport A. G . A probabilistic approach to the prediction of snow loads //Canadian J ournal of Civil Engineering. - 1974. - T. 1. - №. 1. - C. 28-49.

30. K obayashi D. Studies of snow transport in low-level drifting snow //Contributions from the Institute of Low Temperature Science. - 1972. - T. 24. - C. 1-58.

31. G amble S. L ., K ochanski W. W ., I rwin P. A. Finite area element snow loading prediction-applications and advancements //J ournal of wind engineering and industrial aerodynamics. - 1992. - T. 42. - №. 1-3. C. $1537-1548$.

32. Beyers J. H. M., Sundsbø P. A., Harms T. M. Numerical simulation of threedimensional, transient snow drifting around a cube //J ournal of Wind Engineering and Industrial A erodynamics. - 2004. - T. 92. №. 9. - C. 725-747.

33. Tominaga $\mathbf{Y}$, et al. CFD prediction of snowdrift around a cubic building model //The fourth international symposium on computational wind engineering (CWE2006), Y okohama, Japan. - 2006. C. 941-944.

34. Thiis T, $\mathbf{K}, \mathbf{O}$ 'R ourke $\mathbf{M}$, M odel for snow loading on gable roofs //J ournal of Structural Engineering. - 2015. - T. 141. - №. 12. - C. 04015051.

35. Tominaga $Y$, et al. CFD simulation of drift snow loads for an isolated gable-roof building //8th International Conference on Snow Engineering. - Nantes France, 2016. - C. 14-17.

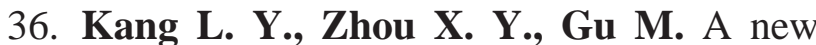
method for predicting snowdrift on flat roofs //Proceedings of the 8th International 
Conference on Snow Engineering, Nantes, France, pp. 137-141 (J une 14-17). - 2016.

37. Zhou X. \& al. Numerical simulation and wind tunnel test for redistribution of snow on a flat roof //J ournal of Wind Engineering and Industrial A erodynamics. - 2016. - T. 153. - C. 92-105.

38. This T. K. A comparison of numerical simulations and full-scale measurements of snowdrifts around buildings //Wind \& structures. - 2000. - T. 3. - №. 2. - C. 7381.

39. This T. K. Large scale studies of development of snowdrifts around buildings I/J ournal of Wind Engineering and Industrial A erodynamics. - 2003. - T. 91. - №. 6. C. 829-839.

40. Beyers M., Waedhter B. M odeling transient snowdrift development around complex three-dimensional structures //Journal of Wind Engineering and Industrial Aerodynamics. - 2008. - T. 96. - №. 10-11. - C. 1603-1615.

41. Okaze T. \& al. CFD prediction of snowdrift in a building array //Proceedings of the 8th International Conference on Snow Engineering, Nantes, France. - 2016. - C. 1417.

42. ASCE/SEI 49-12 Wind Tunnel Testing for Buildings and Other Structures

43. Takeuchi M. Vertical profile and horizontal increase of drift-snow transport //J ournal of Glaciology. - 1980. - T. 26. - №. 94. C. 481-492.

44. Qiang S., Zhou, X., Gu, M., \& Kang, L., 2021. A novel snow transport model for analytically investigating effects of wind exposure on flat roof snow load due to saltation. J. Wind Eng. Ind. Aerodyn., T. 210, 104505.
45. Ma W. et al. Field measurement and numerical simulation of snow deposition on an embankment in snowdrift //Wind and Structures. - 2021. - T. 32. - №. 5. - C. 453-469.

46. ISO 4355-2016 - Bases for design of structures - Determination of snow loads on roofs, IDT.

47. Хитрых Д. П. Опыт моделирования процессов снегопереноса и снегоотложения //ANSYS Advantage. - 2013. - C. $27 Y 32$.

48. Белостоцкий А.М., Акимов П.А., Афанасьева И.Н., Кайтуков Т.Б. О снеговых нагрузках на здания и сооружения // Вопросы прикладной математики и вычислительной механики. Сборник трудов №20. - 2017. - С. 212-215.

49. Белостоцкий А.М., Акимов П.А., Афанасьева И.Н. Вычислительная аэродинамика в задачах строительства. М., Издательство АСВ, 2017, 720 с.

50. Стоянов, В.В., Жгалли, Ш. Численное моделирование снеговых нагрузок на покрытиях уникальных и современных архитектурных форм. - 2019. - Том 30 (69) No 1 Частина 2.

51. Матвеенко Е.В. Обобщенный анализ методов моделирования снеговой нагрузки. // Вестник Брестского государственного технического университета. 2018. №1 - С. 77-80.

52. Белостоцкий А.М., Бритиков Н.А., Горячевский О.С. Сравнение нормативных документов различных стран в части назначения снеговых нагрузок // International Journal for Computational Civil and Structural Engineering. - 2021. T. 17. - №. 3. - C. 39-47.
Belostotsky Alexander Mikhailovich, RAACS academician, professor, D.Sc. in Engineering; General Director of Scientific Research Center StaDyO; Professor of the Department of Informatics and Applied Mathematics and Scientific Director of the A.B. Zolotov NICCM of the National Research Moscow State University of Civil
Engineering; Professor of the Department of Building Structures, Buildings and Structures of the Russian University of Transport (MIIT); 125040, Russia, Moscow, 3rd Yamsky Pole, 18, office 810; Tel. +7 (499) 706-88-10 E-mail: amb@stadyo.ru 
Critical Review of Modern Numerical Modelling of Snow Accumulation on Roofs with Arbitrary Geometry

Britikov Nikita Aleksandrovich, engineer of the A.B. Zolotov NICCM of the National Research Moscow State University of Civil Engineering; postgraduate student of the Russian University of Transport (MIIT); 129337, Russia, Moscow, Yaroslavskoe shosse, 26. E-mail: n.a.britikov@gmail.com

Goryachevsky Oleg Sergeevich, Lead Computing Engineer of Research Center StaDyO; Deputy Director of the A.B. Zolotov NICCM of the National Research Moscow State University of Civil Engineering; 129337, Russia, Moscow, Yaroslavskoe shosse, 26. E-mail: osgoryachevskij@mail.ru

Белостоикий Александр Михайлович, академик РААСН, профессор, доктор технических наук; генеральный директор ЗАО Научно-исследовательский центр СтаДиО; профессор кафедры Информатики и прикладной математики Национального исследовательского, научный руководитель НОЦ КМ им. А.Б. Золотова Московского государственного строительного университета; про- фессор кафедры «Строительные конструкции, здания и сооружения» Российского университета транспорта (МИИТ); 125040, Россия, Москва, ул. 3-я Ямского Поля, д.18, офис 810; тел. +7 (499) 706-88-10. E-mail: amb@stadyo.ru

Бритиков Никита Александрович, инженер НОЦ КМ им. А.Б. Золотова Национального исследовательского Московского государственного строительного университета; аспирант Российского университета транспорта (МИИТ); 129337, Россия, г. Москва, Ярославское шоссе, д. 26. E-mail: n.a.britikov@gmail.com.

Горячевский Олег Сергеевич, ведущий инженер-расчетчик ЗАО Научно-исследовательский центр СтаДиО; заместитель директора НОЦ КМ им. А.Б. Золотова Национального исследовательского Московского государственного строительного университета; 129337 , Россия, г. Москва, Ярославское шоссе, д. 26. E-mail: osgoryachevskij@mail.ru 